\title{
Rare and Extreme Wildland Fire in Sakha in 2021
}

\author{
Hiroshi Hayasaka
}

Citation: Hayasaka, H. Rare and Extreme Wildland Fire in Sakha in 2021. Atmosphere 2021, 12, 1572. https://doi.org/10.3390/ atmos12121572

Academic Editor: Theodore M. Giannaros

Received: 10 October 2021 Accepted: 26 November 2021 Published: 27 November 2021

Publisher's Note: MDPI stays neutral with regard to jurisdictional claims in published maps and institutional affiliations.

Copyright: (C) 2021 by the author. Licensee MDPI, Basel, Switzerland. This article is an open access article distributed under the terms and conditions of the Creative Commons Attribution (CC BY) license (https:/ / creativecommons.org/licenses/by/ $4.0 /)$.
Arctic Research Center, Hokkaido University, Sapporo 0010021, Japan; hhaya@eng.hokudai.ac.jp

\begin{abstract}
A large-scale wildland fire occurred in Sakha in 2021. The results of fire analysis showed that the total number of hotspots in 2021 exceeded 267,000. This is about 5.8 times the average number of fires over the last 19 years since 2002. The largest daily number of hotspots in 2021 was 16,226, detected on 2 August. On 7 August, about half of the daily hotspots $(52.6 \%=8175 / 15,537 \times 100)$ were detected in a highest fire density area (HFA, $\left.62.5-65^{\circ} \mathrm{N}, 125-130^{\circ} \mathrm{E}\right)$ near Yakutsk under strong southeasterly wind (wind velocity about $12 \mathrm{~m} / \mathrm{s}(43 \mathrm{~km} / \mathrm{h})$ ). The results of weather analysis using various weather maps are as follows: The large meandering westerlies due to stagnant low-pressure systems in the Barents Sea brought high-pressure systems and warm air masses from the south to high latitudes, creating warm, dry conditions that are favorable conditions for fire. In addition to these, strong southeasterly winds at lower air levels blew which were related to the development of high-pressure systems in the Arctic Ocean. The HFA was located in the strong wind region $(>8 \mathrm{~m} / \mathrm{s}$ ) of the $\mathrm{v}$-wind map. The record-breaking Sakha fire season of 2021 is an example of extreme phenomena wrought by rapid climate change.
\end{abstract}

Keywords: wildland fire; hotspot; fire weather; climate change; warm air mass; advection; meandering of westerlies

\section{Introduction}

Arctic amplification (AA) - referring to the enhancement of near-surface air temperature change over the Arctic relative to lower latitudes-is a prominent feature of climate change with important impacts on human and natural systems [1]. The strong amplification of global warming in the Arctic has accelerated the thaw rate of the permafrost [2] and fire activity. Weather and climate are the most important factors influencing fire activity and these factors are changing due to human-caused climate change [2].

Under a warmer climate in the future, more severe fire weather, more area burned, more ignitions and a longer fire season are expected [3]. In recent years, the pan-Arctic region has experienced increasingly extreme fire seasons [4].

Gillett et al. [5] have suggested that the observed increase in area burned in Canada during the last four decades is the result of human-induced climate change. Additionally, it appears that temperature is the most important predictor of area burned in Canada and Alaska with warmer temperatures associated with increased area burned [6,7].

Siberia is within the region of observed and predicted future accelerated climate change [8]. Increased air temperature may lead to an increase in wildfire frequency and burned area [9]. According to some previous publications, the annual burned area in Russia was estimated as $40 \times 10^{3} \mathrm{~km}^{2}-200 \times 10^{3} \mathrm{~km}^{2}[10,11]$. According to official data, the annual burned area was $5.5 \times 10^{3} \mathrm{~km}^{2}-24 \times 10^{3} \mathrm{~km}^{2}$ [12]. More than $70 \%$ and up to $90 \%$ (i.e., $20 \times 10^{3} \mathrm{~km}^{2}-140 \times 10^{3} \mathrm{~km}^{2}$ annually) of the total area burned in Russia occurred in Siberia [11,13].

The majority ( $>50 \%$ ) of wildfires in Siberia were observed in larch (Larix sibirica), because it dominated forest communities and because of its low crown closure that spread surface fires [9]. The dense lichen and moss ground cover can support severe ground fires covering up to several million hectares. Due to the shallow root zone (limited by permafrost) those 
wildfires were mostly stand-replacing fires [14]. Thus, the largest area of stand-replacement fires $\left(5.8 \times 10^{3} \mathrm{~km}^{2}\right)$ in the last decade occurred in Sakha (northeast Siberia) [15].

Fire size is sensitive to weather in the days to weeks following ignition, particularly the postignition timing of precipitation [16]. For example, prolonged periods of warm and dry conditions coincident with atmospheric blocking that persisted for several weeks after ignition enabled the growth of large forest fires. Extensive fires in 2004 may have been related to a persistent blocking ridge over Alaska [17,18]. The burnt area in the North American boreal forest was controlled by the frequency of mid-tropospheric blocking highs that caused rapid fuel drying $[19,20]$. Furthermore, $500 \mathrm{hPa}$ height anomalies were well correlated with the seasonal burnt area over large regions of Canada and Alaska [21,22].

In earlier work we collaborated with researchers in Alaska and Sakha in 2005 to analyze wildland fire using fire history and weather data (rainfall, temperature, and wind). Increased fire activity has been observed since approximately 1990 for the periods of 1950-2015 in Alaska and 1955-2009 in Sakha [23,24], concurrent with increasing temperatures [2,5,23-25]. Subsequently, we performed a daily fire analysis using daily hotspot (HS) data and weather maps, including temperature and wind, to understand fire weather during the active fire-period in eastern Siberia and Alaska. Our analysis results [26-28] clearly showed that fires during all active-fire periods became very active as warm air masses (cTe: continental temperate [29]) from the south approached the four study regions. These movements of warm air masses were mainly related to the meandering of large westerlies. Strong wind conditions occurred when warm and dry air masses were approaching, stagnating, and passing over southern Sakha under various weather conditions at lower air level [26-28].

This paper focuses on fires in Sakha, especially fires in 2021. Fire weather during active fire periods was analyzed using various weather maps, including temperature and wind at upper and lower air levels, as in our previous report [26-28].

\section{Methods and Data}

\subsection{Study Region}

Sakha, in the republic of the Russian Federation in eastern Siberia, lies between around $56-73^{\circ} \mathrm{N}$ and $106-160^{\circ} \mathrm{E}$, as shown in Figure 1. The study region covers most of Sakha (red rectangle; $57.5-72.5^{\circ} \mathrm{N}, 110-140^{\circ} \mathrm{E}$ ) except the northeastern area. The study region is about $2.3 \times 10^{6} \mathrm{~km}$ and covers roughly about $74 \%$ of Sakha $\left(3.1 \times 10^{6} \mathrm{~km}\right)$. Yakutsk, the capital of Sakha, is located at slightly southeast of the center of the study region (around $62^{\circ} \mathrm{N}$ and $129.8^{\circ}$ E). Sakha's boreal forest or taiga lies mainly in the south of the Arctic Circle and in the southcentral part of Sakha, which is underlain by permafrost. Sakha's forests consist mainly of larch, pine, and spruce, with a ground cover of Vaccinium vitisidaea, moss, and lichen.

Figure 1 shows the total number of hotspots (rounded value of $\mathrm{HS}, \times 10^{3}$ ) over the last 19 years (2002-2020) in 36 blocks within the study region. From these numbers, we can see that most fire areas occurred in the south-central part of Sakha. In 2021, a very large number of HSs $(=65,102)$ were detected in one block (orange rectangle in Figure 1, 62.5-65 $\mathrm{N}$, $\left.125-130^{\circ} \mathrm{E}\right)$, hereafter referred to as the "highest fire density area" or "HFA"). Although the area of the HFA comprises only about $2.9 \%$ of the total study area, it accounted for about $24 \%$ $(=65,102 / 267,677 \times 100)$ of hotspots detected in 2021.

\subsection{Hotspot (Fire) and Weather Data}

Hotspot (HS) data over 20 years (from 1 July 2002 to 5 September 2021) detected by moderate resolution imaging spectroradiometer (MODIS) on the Terra and Aqua satellites were used to evaluate fires in the study region of Sakha. MODIS HS data were obtained from the NASA Fire Information for Resource Management System (FIRMS; MODIS Collection 6, https:/ / firms.modaps.eosdis.nasa.gov / download/, latest access: 10 September 2021). The minimum size of the hotspots is $1 \mathrm{~km}$. We used only the spatial and temporal hotspot data. The number of daily hotspots is used to identify an active fire period and the important dates of major hotspot peaks during the fire periods. 


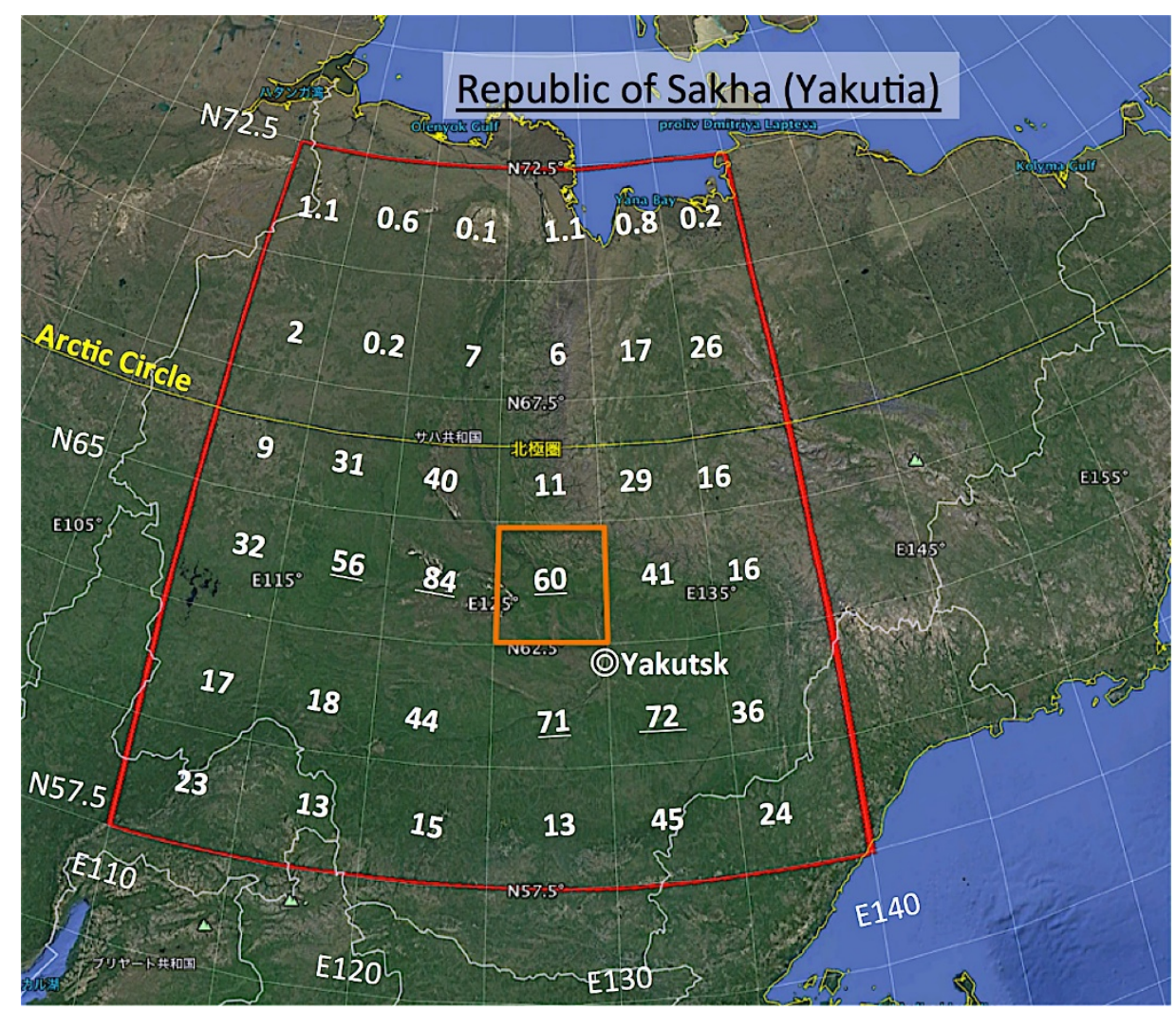

Figure 1. Map of the Republic of Sakha. The region was divided into 36 blocks showing the total number of hotspots $\left(\times 10^{3}\right)$ from 2002 to 2020 . The ground total of the hotspots was 877,603 . The distance from west to east (from $110^{\circ}$ to $140^{\circ} \mathrm{E}$ ) is about $1520 \mathrm{~km}$ at $62.5^{\circ} \mathrm{N}$. The distance from south to north (from $57.5^{\circ}$ to $72.5^{\circ} \mathrm{N}$ ) is about $1670 \mathrm{~km}$. The orange rectangle is the highest fire density area (HFA). Base map made by "Google Earth Pro".

Active fire occurrence and burn scars in Sakha were also confirmed by checking the satellite imageries (Corrected Reflectance (true color), MODIS on Terra) of Worldview (https:/ / worldview.earthdata.nasa.gov, latest access: 6 October 2021). Worldview provides various fire-related information such as smoke from fire, smoke direction, surface conditions, cloud distribution, clear sky area, and so on.

Various weather maps such as pressure, wind, and temperature at upper air level $(500 \mathrm{hPa})$ and lower air level $(925 \mathrm{hPa})$ are obtained from the NCEP/NCAR 40-year reanalysis data [30]. We analyzed them to find fire weather conditions during active fire periods, fire-related synoptic scale circulation patterns, movement of warm air masses and so on. We call warm air masses cTe (continental temperate) [29] in this paper. Coverage and spatial resolution of the NCEP reanalysis data are: Geographic longitude and latitude: $0.0^{\circ} \mathrm{E}$ to $358.125^{\circ} \mathrm{E},-88.542^{\circ} \mathrm{N}$ to $88.542^{\circ} \mathrm{N}$. Spatial resolution: about $2.5^{\circ} \times 2.5^{\circ}$. Period and temporal resolution: 1948/01/01 to now, 6-hourly, daily and monthly. Wind velocity and wind direction were obtained from $\mathrm{u}$ - and v-distribution maps at a lower air level $(925 \mathrm{hPa})$. Weather data in Yakutsk (capital of Sakha) were also obtained from World Weather Online to check ground-level weather conditions (https:/ / www.worldweatheronline.com, latest access: 6 October 2021).

As the above-mentioned weather maps are usually used for weather forecast, fire forecast and alerts could easily made by adding real-time fire information from satellite hotspot data. In addition to the above-mentioned maps, we introduced a new wind rating approach using $\mathrm{v}$ - and $\mathrm{u}$-wind maps to clarify the relationship between fire and wind. This wind rating method will improve the accuracy of fire forecasts for the local area. 


\subsection{Analysis Methods}

MODIS hotspot data were used to identify fire history in Sakha from 2002, and fire activity and distribution in 2021. An active fire period is defined here as consecutive fire days when the number of daily hotspots is greater than 1000 [25].

Analysis using various weather maps at lower and upper air levels was carried out to confirm fire weather conditions during active fire periods [25-28]. In this paper, $\mathrm{v}$ - and $\mathrm{u}$-wind maps at lower air levels were used to not only calculate wind velocity and direction at a reference point but also to identify strong wind area.

Computer-Aided Design (CAD, Vector-Works ver. 2014 SP4) software was used to process hotspot data using programming language (mini-Pascal) and to plot the hotspots on each weather map.

\section{Results}

Based on results from our previous papers [26-28], we made various synoptic-scale weather, temperature, and wind maps with hotspots (fire) to understand the very active 2021 fire season in Sakha.

\subsection{Recent Fire History}

Figure 2 shows fire history from 2002 to 2020, and 2021 (until 9 September) using the daily number of HSs. The grand total number of HSs over the 19 years from 2002 to 2020 was 877,606, and the average number of HSs was 46,190 annually. Each bar graph is divided into six parts (every $2.5^{\circ}$ from $57.5^{\circ}$ to $72.5^{\circ} \mathrm{N}$ ) detailing fire occurrence by latitudes. The number of HSs in nine years (2002, 2011, 2012, 2013, 2014, 2018, 2019, 2020, and 2021) exceed the average annual value and will be referred to as "High Fire Year".

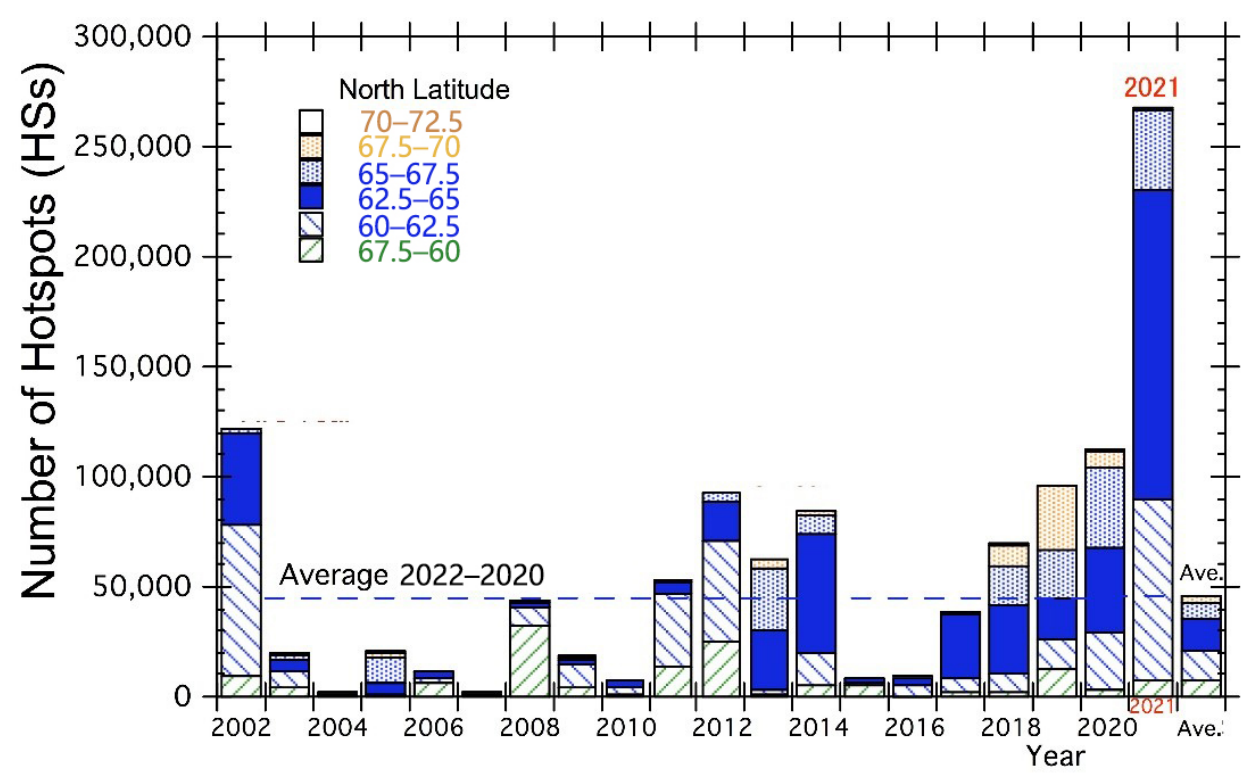

Figure 2. Recent fire history in Sakha from 2002 to 2020, and 2021 (until 9 September).

In 2021, the accumulated daily number of HSs up to 9 September was $267,677-5.82$ times larger than average values of the previous 19 years. Thus, 2021 was by far the most active fire season on record, followed by 2002.

\subsection{Fire in 2021}

\subsubsection{Hotspot (Fire) Distribution}

Table 1 shows the latitude and longitude distribution of HS (fire) in the study region of Sakha. In 2021, largest number of HSs among 36 blocks (see Figure 1) is 65,102 in the block $\left(62.5-65^{\circ} \mathrm{N}, 125-130^{\circ} \mathrm{E}\right)$. This number is larger than the 60,000 shown in Figure 1 (the actual number is 60,171 , the total number of hotspots over the last 19 years from 2002). 
This highest fire area (HFA) is located in the northwest of Yakutsk. The second largest number of HSs is 31,861 in the block ( $\left.62.5-65^{\circ} \mathrm{N}, 115-120^{\circ} \mathrm{E}\right)$. Percentages of the top and second HFA out of the total number of HSs $(267,677)$ are 24.3 and $11.9 \%$, respectively. These high percentages indicate that fire in 2021 occurred mainly in both areas of Sakha. In other words, a very large number of HSs is the result of these concentrated fires.

Table 1. Hotspot (HS) distribution in Sakha in 2021 until 9 September.

\begin{tabular}{|c|c|c|c|c|c|c|c|}
\hline \multicolumn{8}{|c|}{ East Longitude $110-140^{\circ} \mathrm{E}$} \\
\hline & & $110-$ & $115-$ & $120-$ & $125-$ & $130-$ & $135-$ \\
\hline & $70-$ & 18 & 39 & 4 & 0 & 19 & 0 \\
\hline & $67.5-$ & 47 & 0 & 29 & 66 & 136 & 212 \\
\hline & $65-$ & 191 & 11,766 & 17,286 & 5938 & 945 & 493 \\
\hline \multirow[t]{3}{*}{$57.5-72.5^{\circ} \mathrm{N}$} & $62.5-$ & 16,702 & $31,861^{2}$ & 11,339 & $65,102^{1}$ & 11,900 & 3923 \\
\hline & $60-$ & 7101 & 4292 & 23,876 & 27,813 & 11,324 & 8358 \\
\hline & $57.5-$ & 328 & 1313 & 1044 & 476 & 2439 & 1296 \\
\hline
\end{tabular}

${ }^{1}$ Number of HSs for the highest fire area (HFA). ${ }^{2}$ HSs for the second highest fire area. The ground total of hotspots was $267,677$.

\subsubsection{Daily Fire Occurrence}

The blue line and red line in Figure 3 show the daily fire tendency occurrence using the daily number of hotspots (HSs) in Sakha, and the highest fire area (HFA). To discuss fire weather, we defined that only one fire period started around 27 July (Day Number $(D N)=208$, HSs $=1702$ ) and ended on 10 August ( $\mathrm{DN}=222, \mathrm{HSs}=3298$ ) as shown in Figure 3. Total number of HSs during the active fire period was 51,381 , which was about $79 \%$ of all HSs $(65,102$, see Table 1$)$ of the fire season in 2021.

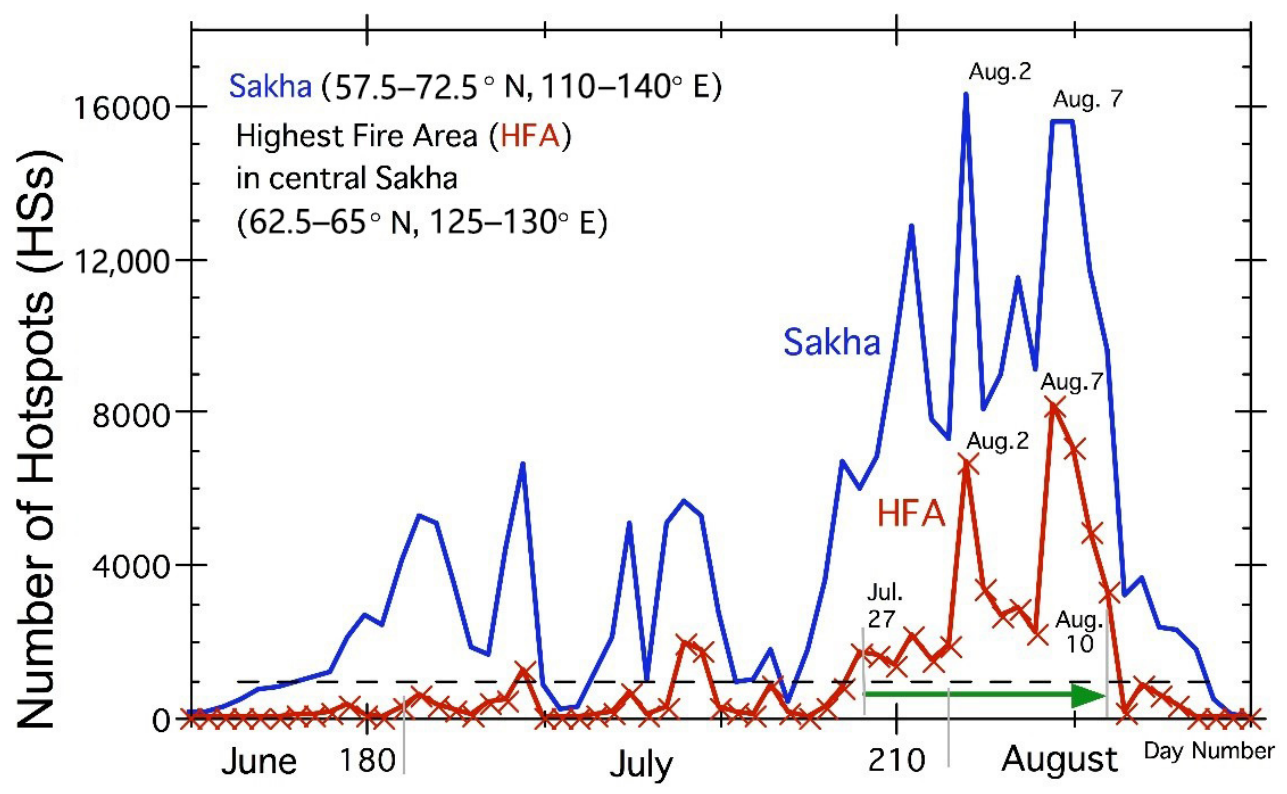

Figure 3. Daily fire occurrence in 2021. The blue line is for Sakha. The red line with red $x$ mark is for the highest fire area (HFA).

Very large numbers extracted from daily HSs data are itemized below to characterize extreme fires in 2021.

- The largest daily number of HSs in 2021 was 16,226, detected on 2 August. This is larger than 10,454, the second largest number of HSs detected on 19 August 2002. As the third largest daily number of HSs was 8282, detected on 4 August 2012, we may say that 2021 had very active daily fire after 2002. 
- $\quad$ Total number of HSs of the HFA in 2012 was 65,102 (see Table 1). This number exceeds 60,171 , the total number of HSs of 19 years (2002-2020). This is about 21 times the average value over those 19 years (3167).

- The daily highest number of HSs in the HFA was 8175, detected on 7 August (larger than the above-mentioned value of 8282, detected on 4 August 2012 in Sakha). The second peak of HS was 6661, on 2 August.

From the above-described, very large figures for fires in the HFA in 2021, we may say that rare and extreme (very active) fire occurred in one small area (the HFA, only about $2.9 \%$ of the total study area) in Sakha.

In the next section, we will discuss fire weather during the very active fire period in the HFA using various weather maps.

\subsection{Weather Conditions during the Active Fire Period in the HFA}

\subsubsection{Large Meandering of Westerlies at Upper Air Level (500 hPa)}

Large meandering of westerlies will create persistent fire weather conditions at high latitude. This is due to persistent high-pressure "blocking" weather systems, which bring clear, dry conditions on the ground below for many days or weeks [31]. Large meandering of westerlies and persistent high-pressure systems are essential weather phenomena for active fire in boreal wildland [21,22,26-28].

Figure 4 shows large meandering of westerlies on 24 July due to the stagnant lowpressure systems $\left(\mathrm{L}_{5300}\right.$, at around $\left.73^{\circ} \mathrm{N}, 45^{\circ} \mathrm{E}\right)$ in western Siberia. This stagnation started around 22 July and ended around 31 July. Persistent high-pressure systems $\left(\mathrm{H}_{5820}\right.$, at around $63^{\circ} \mathrm{N}, 95^{\circ} \mathrm{E}$ ) in Figure 4 firstly appeared on 24 July and lasted until around 8 August. The number of HSs in Sakha on 24 July was 1776.

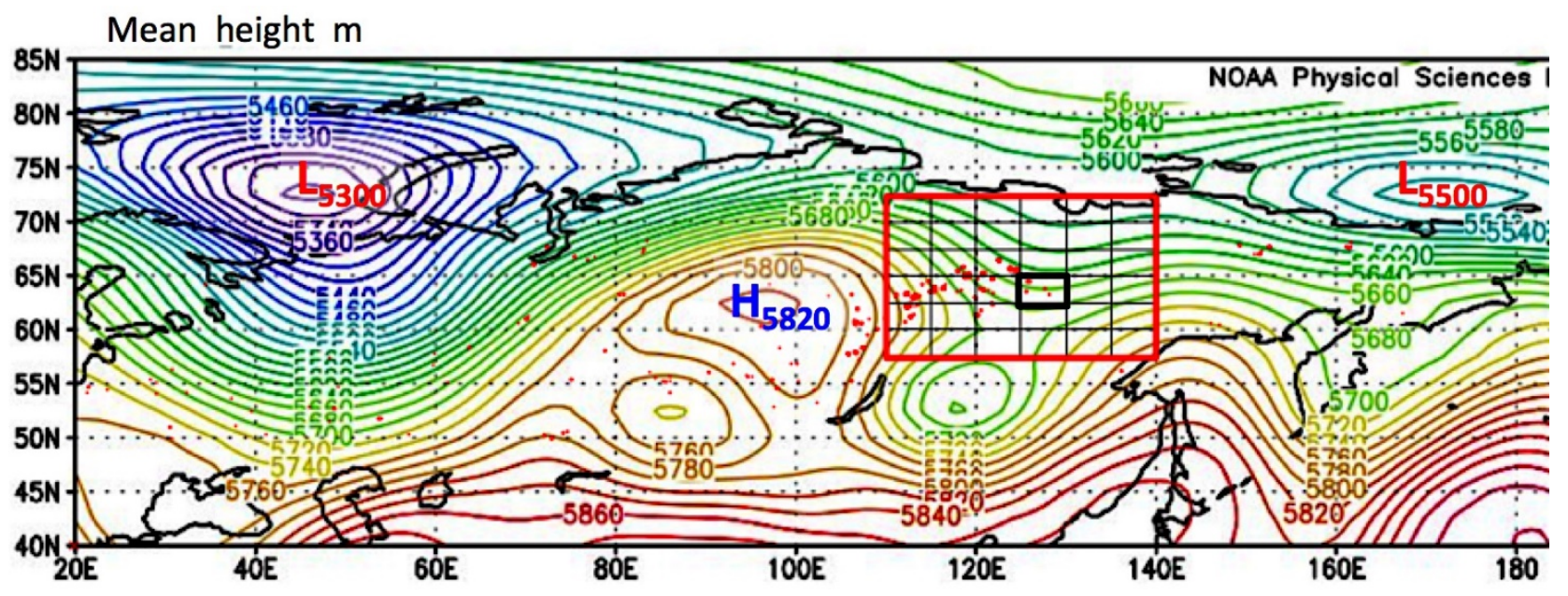

Figure 4. Large meandering of westerlies on 24 July. The study region (Sakha) is shown by the rectangle with the red line. HFA is shown by the rectangle with the thick black line. The hotspot (HS) is shown by the red dot.

\subsubsection{High-Pressure Systems over Sakha at Upper Air Level (500 hPa)}

High-pressure systems in East Siberia on 2 and 7 August are shown in Figure 5a,b. Highpressure systems in Figure 4 gradually moved to the northeast and developed from $5820 \mathrm{~m}$ $\left(\mathrm{H}_{5820}, 63^{\circ} \mathrm{N}, 95^{\circ} \mathrm{E}\right)$ to $5860 \mathrm{~m}\left(\mathrm{H}_{5860}, 66^{\circ} \mathrm{N}, 122^{\circ} \mathrm{E}\right)$ on 1 August. Figure 5 a shows high-pressure systems $\left(\mathrm{H}_{5820}, 69^{\circ} \mathrm{N}, 120^{\circ} \mathrm{E}\right)$ over the Sakha region on 2 August. Under the high-pressure systems, a very large number of hotspots (HSs) were detected. The total of 16,226 HSs in Sakha was highest HS peak in 2021. The 6661 HSs in the HFA was the second HS peak.

Figure $5 \mathrm{~b}$ shows that the high-pressure systems $\left(\mathrm{H}_{5860}, 70^{\circ} \mathrm{N}, 144^{\circ} \mathrm{E}\right)$ near the study region on August 7 moved from the northeast and developed (from $5825 \mathrm{~m}$ to $5860 \mathrm{~m}$ ). The large number of HSs $(=15,537)$ in Sakha was third highest HS peak. The number of HSs $(=8175)$ detected in the HFA was the highest HS peak. 


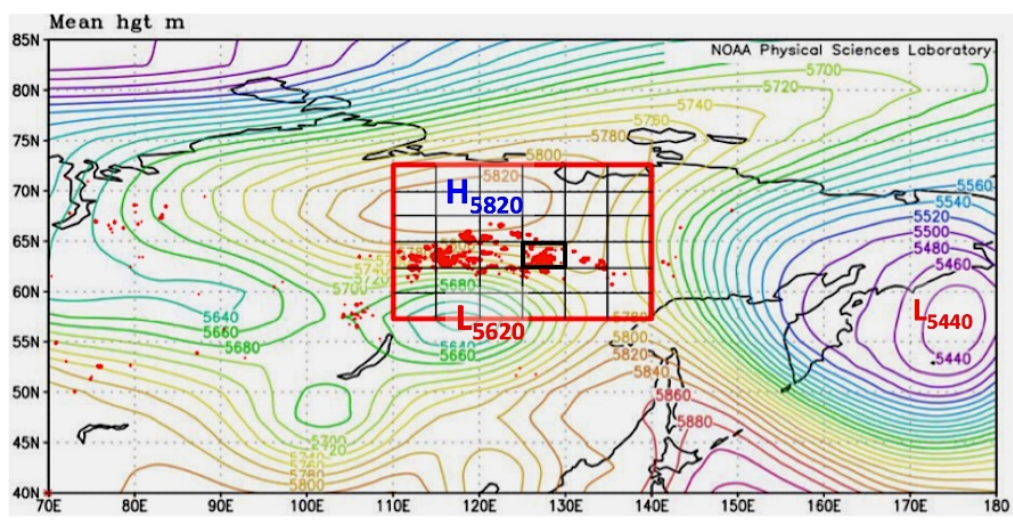

(a)

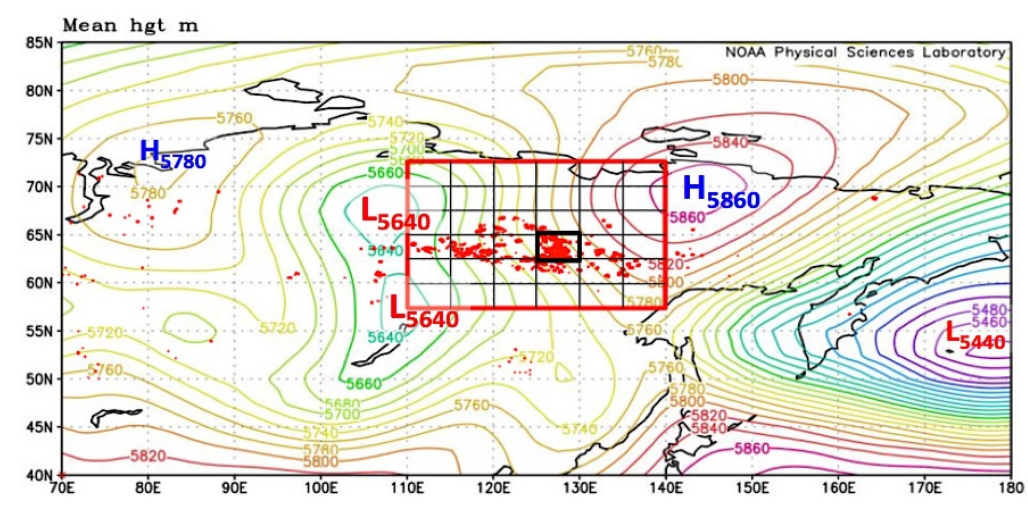

(b)

Figure 5. (a) Weather map on 2 August. See captions for Figure 4, (b) weather map on 7 August. See captions for Figure 4.

\subsubsection{Warm Air Mass at Lower Air Level $(925 \mathrm{hPa})$}

Warm air masses (cTe) detached from the subtropical high-pressure belt at latitude $30-40^{\circ} \mathrm{N}$ moved northward due to advection made by large westerly meandering. We already analyzed 13 active fire periods in four boreal regions in Sakha, Alaska, Krasnoyarsk, and Khabarovsk, and reported active fire occurrences under cTe [26-28].

Figure 6a shows warm air masses (cTe, $296 \mathrm{~K}$ ) firstly observed at $63^{\circ} \mathrm{N} 90^{\circ} \mathrm{E}$ on July 24. Sakha already had 1775 HS. Warm air masses on August 2 (highest HS peak day in Sakha) and 7 August (highest HS peak day in the HFA) are shown in Figure $6 b, c$, respectively. cTe (296 K) on 2 August existed in the western central part of Sakha, and the maximum number of hotspots (HSs $=16,226$ ) for Sakha were detected. On 7 August, the HFA (small, black rectangle in Figure $6 \mathrm{c}$ ) had highest number of HSs $(=8175)$ under the existence of cTe $(291 \mathrm{~K})$ in the central part of Sakha, as shown in Figure 6c.

\subsubsection{Weather Map at Lower Air Level $(925 \mathrm{hPa})$}

Figure $7 \mathrm{a}-\mathrm{c}$ shows weather conditions on $27 \mathrm{July}, 3$ and 7 August, respectively. The large height (pressure) gradient $(\Delta \mathrm{H})$ over the fire region over Sakha suggests high wind velocity. $\Delta \mathrm{H}$ at the active fire block of Sakha are shown by the value and the line with arrows in Figure $7 \mathrm{a}-\mathrm{c}$. The very large $\Delta \mathrm{H}$ in Figure $7 \mathrm{~b}, \mathrm{c}$ suggests windy conditions or winds around the edges of the high-pressure systems [32]. 


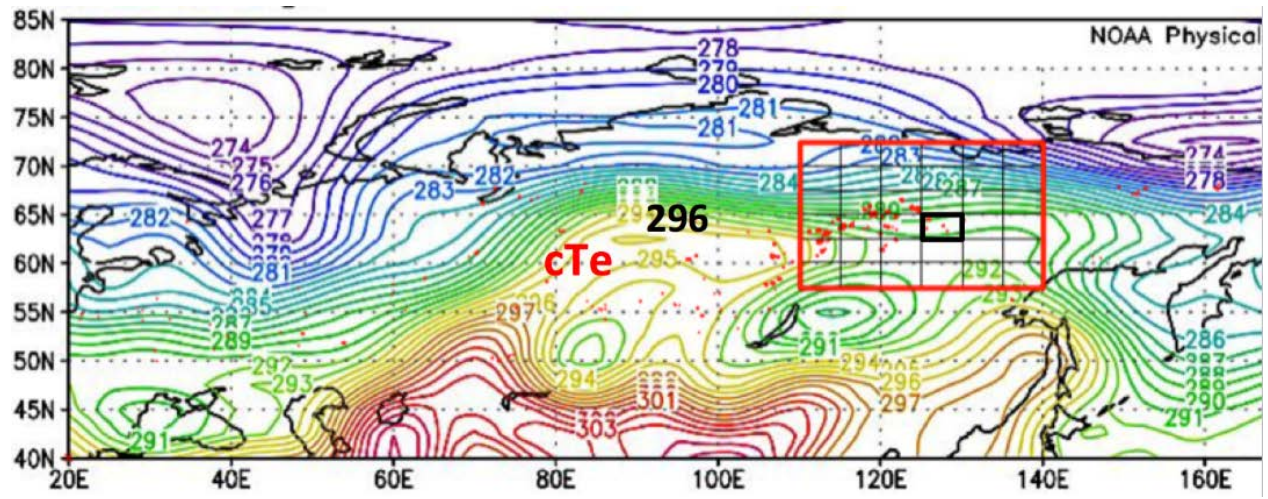

(a)

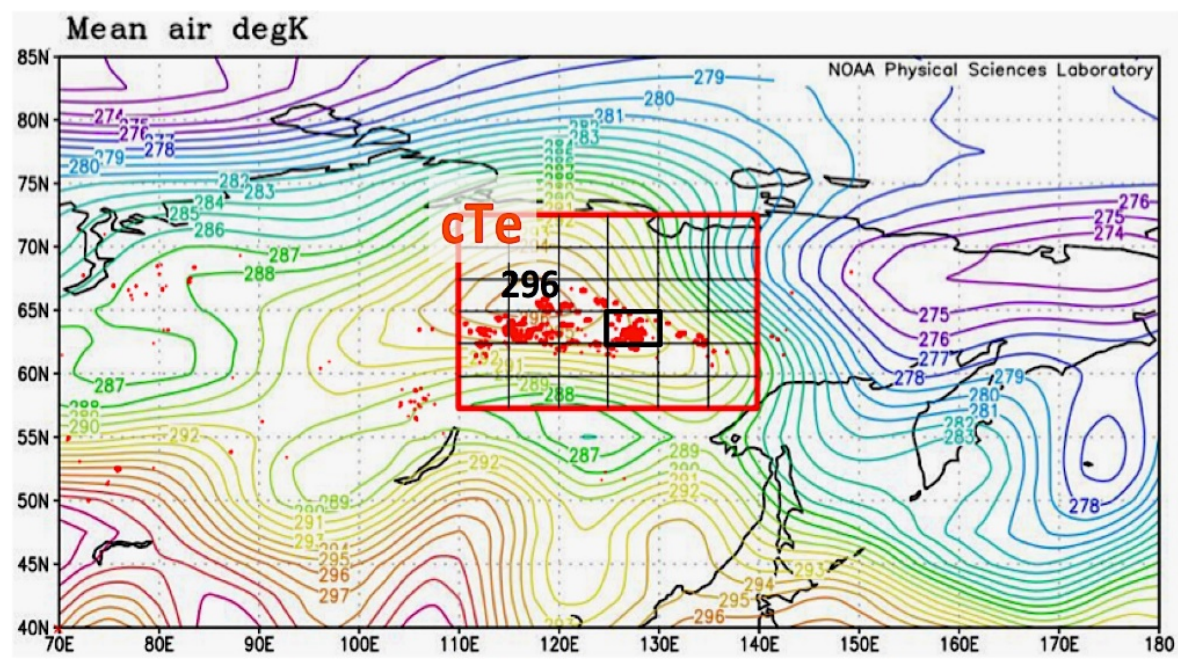

(b)

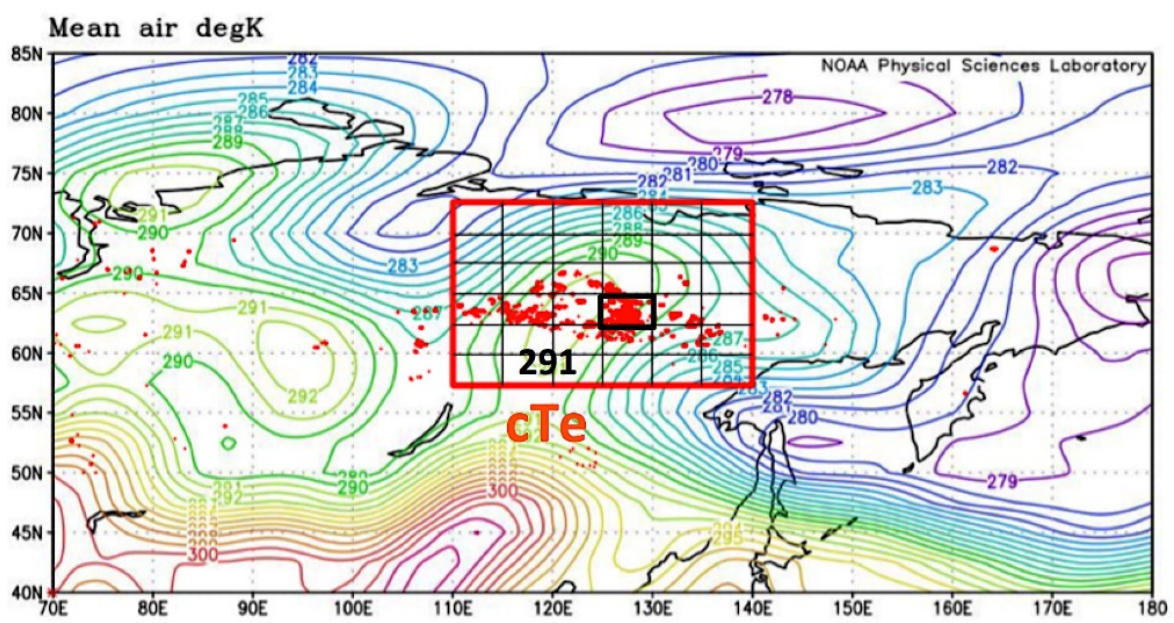

(c)

Figure 6. (a) Temperature map on 24 July. See captions for Figure 4, (b) Largest peak on 2 August. See captions for Figure 4, (c) Largest peak on 7 August. See captions for Figure 4. 


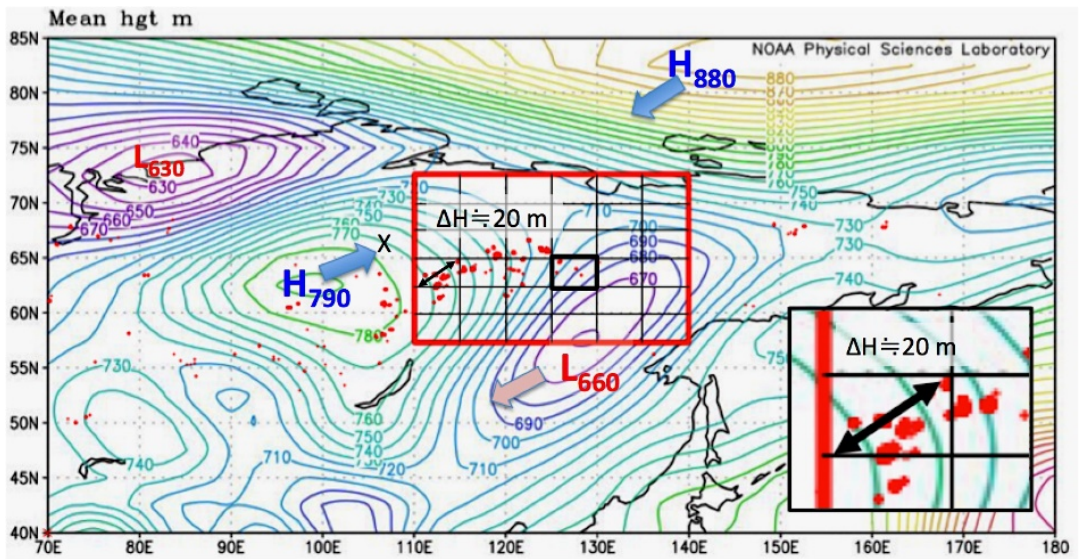

(a)

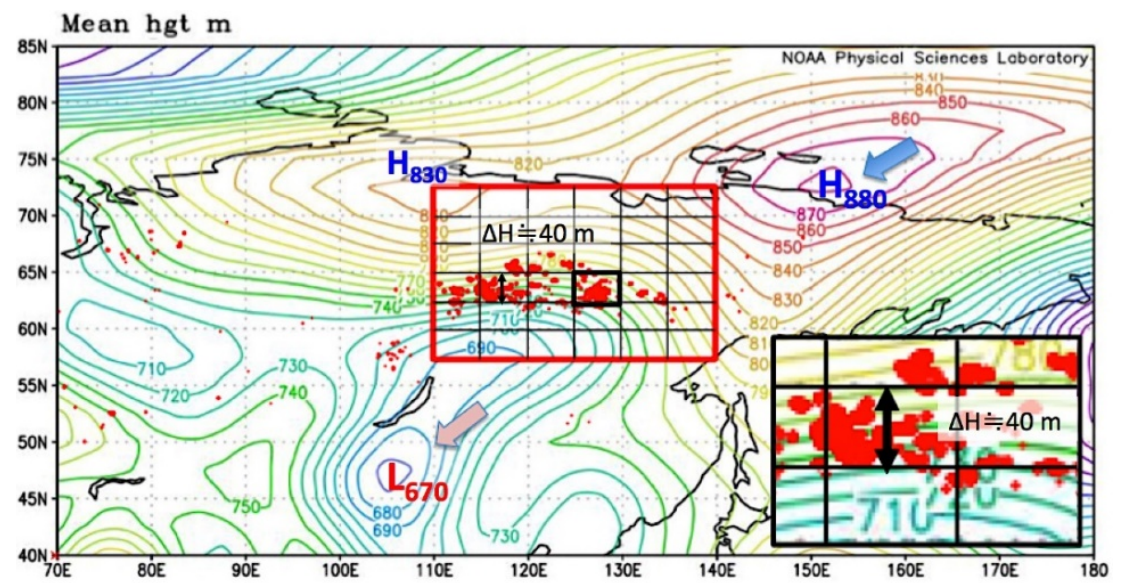

(b)

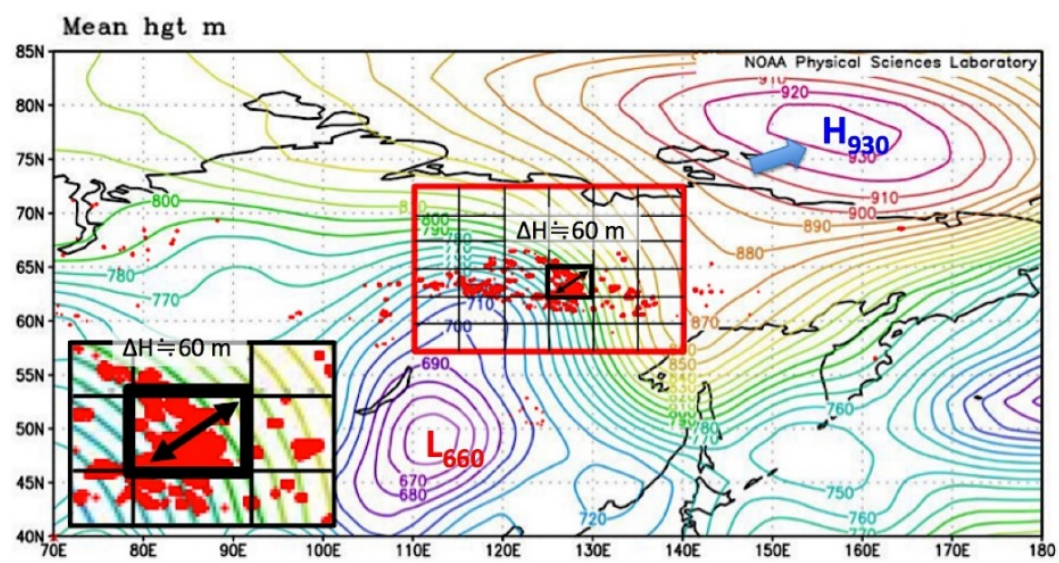

(c)

Figure 7. (a) Weather map on 24 July. Inserted figure shows the largest HS block and is used to show height gradient $(\Delta \mathrm{H})$. See captions for Figure 4, (b) Weather map on 2 August. Inserted figure shows the second HFA and is used to show height gradient $(\Delta H)$. See captions for Figure 4, (c) Weather map on 7 August. Inserted figure shows HFA and is used to show height gradient $(\Delta \mathrm{H})$. See captions for Figure 4 .

High-pressure systems $\left(\mathrm{H}_{790}, 63^{\circ} \mathrm{N}, 99^{\circ} \mathrm{E}\right)$ in Figure 7a moved in from the south and developed until 26 July. From 27 July, high-pressure systems from the north moved into northern Sakha and developed. Under developed, high-pressure systems, $\mathrm{H}_{880}\left(73^{\circ} \mathrm{N}, 152^{\circ} \mathrm{E}\right)$ and $\mathrm{H}_{830}\left(72^{\circ} \mathrm{N}, 110^{\circ} \mathrm{E}\right)$ in Figure $7 \mathrm{~b}$, fires (HSs) in the middle latitude of Sakha became very 
active under large $\Delta \mathrm{H}(=40 \mathrm{~m}$ in the central western block of Sakha). In Figure $7 \mathrm{c}$, larger $\Delta \mathrm{H}$ $(=60 \mathrm{~m})$ due to $\mathrm{H}_{930}\left(78^{\circ} \mathrm{N}, 155^{\circ} \mathrm{E}\right)$ was found in highest fire area (HFA) in central Sakha.

To clarify the relationship between fire activity and wind condition, wind analysis using $\mathrm{u}$ - and $\mathrm{v}$-wind maps is carried out in the next two sections.

\subsubsection{Wind Velocity at Lower Air Level $(925 \mathrm{hPa})$ and Hotspot (Fire)}

Analysis of wind velocity and wind direction at the lower air level $(925 \mathrm{hPa})$ was carried out using $\mathrm{u}$ - and $\mathrm{v}$-wind maps, by setting the reference point in the highest fire area (HFA) in central Sakha. Wind velocity, wind direction, and number of hotspots (HSs) during the active fire period (27 July-10 August) are shown in Figure 8.

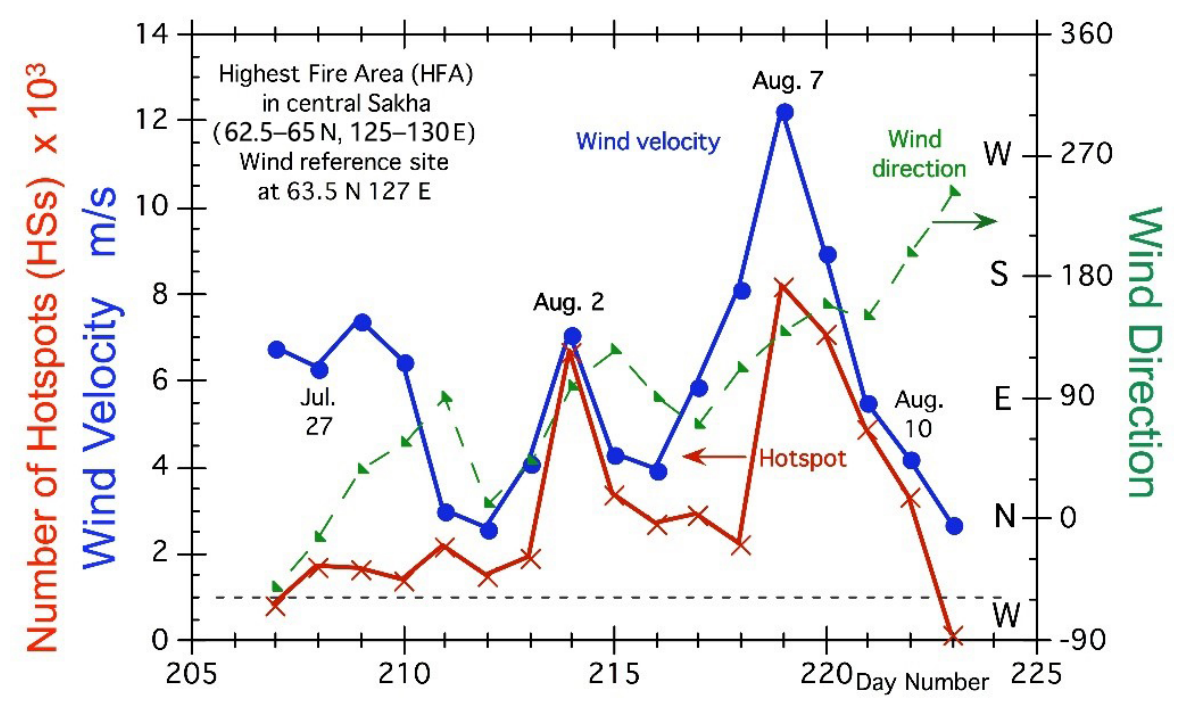

Figure 8. Wind conditions and fire (HS) activity in HFA during the active fire period in 2021.

Wind velocity during the active fire period changed from 2.55 to $11.9 \mathrm{~m} / \mathrm{s}(9.18-42.8 \mathrm{~km} / \mathrm{h})$. During that period, the number of HSs increased from about 1000 to 8000 . The highest hotspot peak (HSs $=8175$ ) on 7 August occurred under the very strong wind velocity of $12.2 \mathrm{~m} / \mathrm{s}(44.1 \mathrm{~km} / \mathrm{h}$ ). Southeasterly strong wind of over $8 \mathrm{~m} / \mathrm{s}(29 \mathrm{~km} / \mathrm{h})$ blew for three days from 6 to 8 August. The second highest hotspot peak (HSs $=6661$ ) on 2 August also occurred under a strong wind velocity of $7.16 \mathrm{~m} / \mathrm{s}(25.8 \mathrm{~km} / \mathrm{h})$. Wind velocity measured at a weather station in Yakutsk was $32 \mathrm{~km} / \mathrm{h}$ (gust $36 \mathrm{~km} / \mathrm{h}$ ) from the southeast at 15:00 on 8 August (World Weather Online).

The change in wind direction during the active fire period from north to south in Figure 8 occurred mainly in relation to the high-pressure systems in Figure 7. Southeasterly wind brought warm air into Sakha. The temperature in Yakutsk was $25^{\circ} \mathrm{C}$ at 15:00 on 8 August (World Weather Online).

\subsubsection{Strong Wind Area in u- and v-Wind Map}

In this section, we will introduce a new wind-rating approach using $\mathrm{v}$ - and $\mathrm{u}$-wind maps to identify strong wind areas. Active hotspot (HS) distribution is shown on the uand v-wind map in Figure 9a,b. HSs of the second hotspot peak on 2 August plotted on the u-wind map in Figure 9a. Figure 9a shows that many HSs are distributed in areas with high easterly wind velocities $(\mathrm{u}<-6 \mathrm{~m} / \mathrm{s})$. Under these easterly wind conditions (see Figure $7 \mathrm{~b}$ or Figure 8), the total number of HSs in Sakha on 2 August were 16,226 (from Table in Figure 9a).

The number of HSs in the second highest HS area $\left(62.5-65^{\circ} \mathrm{N}, 115-120^{\circ} \mathrm{E}\right)$ was 2943 (from Table in Figure 9a). We could estimate wind velocity at the center of the $u$-wind $(u<-10 \mathrm{~m} / \mathrm{s})$ using $\mathrm{u}=-10$ and $\mathrm{v}=-3 \mathrm{~m} / \mathrm{s}$ derived from the v-wind map. Calculated wind velocity was $10.4 \mathrm{~m} / \mathrm{s}(37.6 \mathrm{~km} / \mathrm{h})$ and was faster than the $7.07 \mathrm{~m} / \mathrm{s}$ in the highest fire area (HFA) in Figure 8 . 


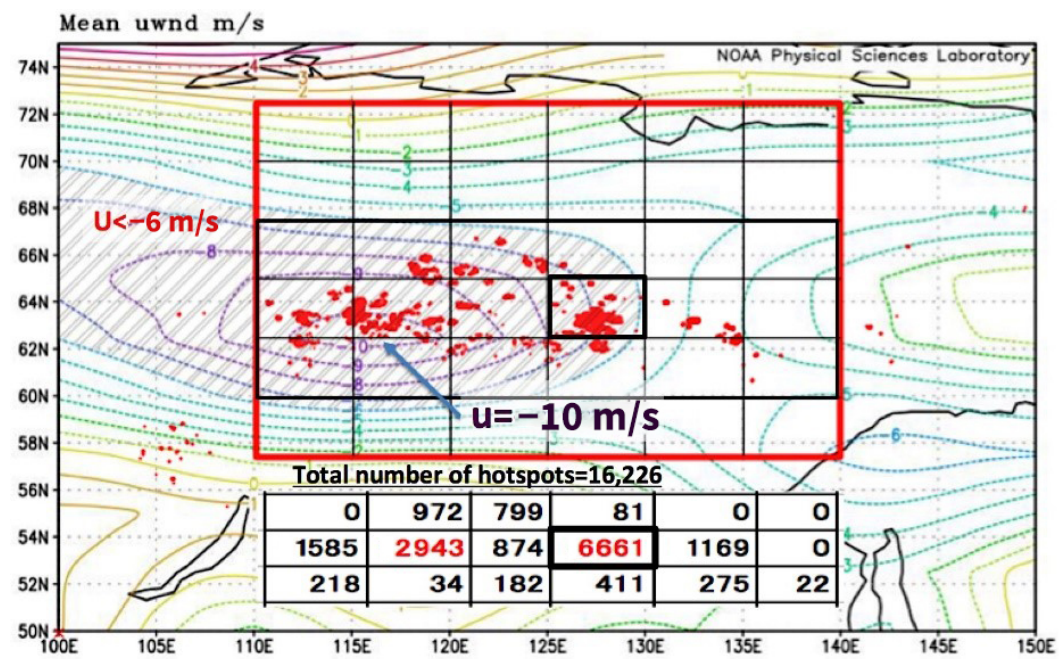

(a)

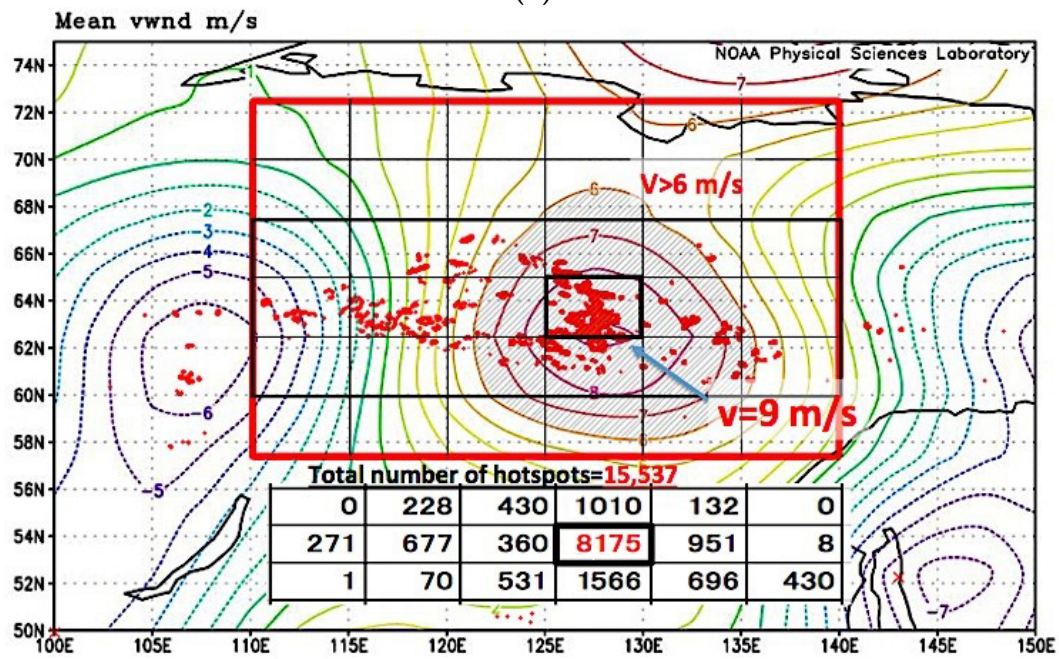

(b)

Figure 9. (a) U-wind map on 2 August. The symbol "-" means easterly wind. Inserted table shows number of HSs in central blocks of Sakha. See captions for Figure 4, (b) V-wind map on 7 August. The symbol "+" means southerly wind. Inserted table shows number of HSs in central blocks of Sakha. See captions for Figure 4.

Hotspots (HSs) of the top hotspot peak on 7 August are plotted on the v-wind map in Figure 9b. Figure 9b clearly shows that many HSs were distributed in the area of high southernly wind velocity $(\mathrm{v}>6 \mathrm{~m} / \mathrm{s})$ in the central part of Sakha. Under strong southeasterly wind (see Figure 7c or Figure 8), the highest fire area (HFA, black rectangle in Figure 9b) in Sakha had very large number of HSs ( 8175 from Table in Figure 9b). The highest southernly wind velocity $(\mathrm{v}>9 \mathrm{~m} / \mathrm{s})$ zone was formed over the HFA. From the wind speed calculation using $\mathrm{v}=9$ and $\mathrm{u}=-8.3 \mathrm{~m} / \mathrm{s}$ derived from the $\mathrm{u}$-wind map, the wind speed was $12.2 \mathrm{~m} / \mathrm{s}(44.1 \mathrm{~km} / \mathrm{h})$. The new wind-rating analysis introduced here will be a useful tools for future fire-fighting, as it may help to identify strong wind areas.

\section{Discussion}

This paper aims to clarify the background of the very active fire in 2021, and to prepare for the next large-scale fire. Before the active fire in 2021, we had already analyzed fire weather conditions during active fires occurring in southern Sakha (SS), northern Krasnoyarsk (NK), southern Khabarovsk (SK), and interior Alaska (IA). In total, 13 active fire periods (six in SS, five in IA, one in NK and in SK) occurred commonly under persistent high-pressure systems, warm air masses cTe (continental temperate), and strong wind 
conditions [25-28]. As the very active fire in 2021 could also be explained by the analysis procedure shown in the previous sections from Section 3.3.1 to Section 3.3.4, our analysis will be useful regarding future active fires. In our analysis, various synoptic-scale weather maps are used to identify the onset of active fire and active-fire weather conditions.

The analysis procedure is summarized below.

1. A weather map at the upper air level $(500 \mathrm{hPa})$ is used to find stagnant low- and highpressure systems and large meandering of westerlies (see Figures 4 and 5). Persistent high-pressure systems over Sakha at the upper air level is one of essential active-fire weather conditions $[21,22,31]$;

2. A temperature map at the lower air level $(925 \mathrm{hPa})$ is used to watch warm air mass (cTe) movement from the south (see Figure 6). cTe over Sakha is one of the essential active conditions;

3. The weather map at the lower air level $(925 \mathrm{hPa})$ is used to capture large height (pressure) gradient areas where strong wind blows (see Figure 7). The very active fire in 2021 occurred under high wind velocity (see Figure 8);

4. In addition to the above weather maps, $\mathrm{u}$ - and $\mathrm{v}$-wind maps at the lower air level $(925 \mathrm{hPa})$ are used to display the strong wind area (see Figure 9). This wind-rating method turned out to be effective and will improve the accuracy of fire forecast in a local area such as the HFA and the second HFA in Figure 9.

We extracted some descriptions about fire weather from "National Wildfire Coordinating Group" (https:/ /www.nwcg.gov/publications/pms437/weather/critical-fire-weather, accessed on 6 October 2021):

a. General nonconvective Red Flag Warning criteria (their warning criteria values are found in Figures 6, 8 and 9) are: Temperature $\geq 23.9{ }^{\circ} \mathrm{C}$ (297 K, (see Figure 6), $\mathrm{RH} \leq 25 \%$, Wind $\geq 6.7 \mathrm{~m} / \mathrm{s}(24.1 \mathrm{~km} / \mathrm{h}$, sustained (see Figures 8 and 9$)$ );

b. The four critical weather elements that produce extreme fire behavior are low relative humidity, strong surface wind, unstable air, and drought;

c. Most periods of critical fire weather occur in transition zones between high- and low-pressure systems, both at the surface and in the upper air;

d. In Alaska, the primary pattern is the breakdown of the upper ridge with a southeastern flow. This can bring gusty winds and dry lightning to the interior of Alaska after a period of hot, dry weather.

Unfortunately, they do not seem to take into account the recent research results for active fires in the boreal region, including Alaska. As large-scale fires in various boreal areas tend to become active as warm air masses (cTe) from the south approach each region, we will be able to make a short-range (a few days at least) fire weather forecast. As our analysis procedure is very simple, we hope that fire managers in the boreal region will experience great benefit by applying our fire weather forecast approach.

\section{Conclusions}

The main conclusions from our analysis results on large-scale wildland fire in Sakha in 2021 are summarized below.

1. The 2021 wildland fire in Sakha was rare and extreme. The total number of hotspots in 2021 exceeded 267,000 . This is about six times the average number of fires over the last 19 years from 2002.

2. The largest daily number of hotspots in 2021 was 16,226, detected on 2 August. On 7 August, about half of daily hotspots $(52.6 \%=8175 / 15,537 \times 100)$ were detected in the highest fire density area (HFA, $62.5-65^{\circ} \mathrm{N}, 125-130^{\circ} \mathrm{E}$ ) near Yakutsk, under strong southeasterly wind (wind velocity was about $12 \mathrm{~m} / \mathrm{s}(43 \mathrm{~km} / \mathrm{h})$ ).

3. The very active fire in August 2021 was caused by large meandering westerlies due to stagnant low-pressure systems from late July in the southern part of the Valentz Sea (L5300, at around $73^{\circ} \mathrm{N}, 45^{\circ} \mathrm{E}$ ). 
4. High-pressure systems at the upper air level $\left(\mathrm{H}_{5820}, 63^{\circ} \mathrm{N}, 95^{\circ} \mathrm{E}\right)$ appeared around 24 July and moved to the Sakha region. Persistent high-pressure systems lasted until around 8 August. Downward flow of high-pressure systems created warm and dry conditions at the lower air level and ground surface.

5. High-pressure systems at the lower air level moved from the Arctic Ocean and developed $\left(\mathrm{H}_{930}, 78^{\circ} \mathrm{N}, 155^{\circ} \mathrm{E}\right)$. Strong wind conditions were made by large pressure difference over Sakha.

6. Warm air masses (continental temperate (cTe)) at the low air level were stagnant over Sakha during the active fire period.

7. Strong wind areas on the $\mathrm{v}$ - and $\mathrm{u}$-wind map coincided with the location of the highest fire density area (HFA) on 7 August and the second HFA on 2 August. This simple wind analysis method is effective to find strong wind areas and will be used for future fire forecast.

The record-breaking Sakha fire season of 2021 is an example of extreme phenomena wrought by rapid climate change. Lastly, we should prepare for the next large-scale fires due to climate change by applying the fire weather analysis approach described in this paper. Our fight against wildland fires is one of the executable ways to mitigate global warming.

Funding: This research received no external funding.

Institutional Review Board Statement: Not applicable.

Informed Consent Statement: Not applicable.

Data Availability Statement: This study used MODIS hotspot data obtained from the NASA Fire Information for Resource Management System. (FIRMS; MODIS Collection 6, https: / firms.modaps. eosdis.nasa.gov/download/, (accessed on 10 September 2021). I used reanalysis data provided by the NOAA/OAR/ESRL PSL, Boulder, CO, USA, from their website at https:/ / psl.noaa.gov / (accessed on 6 October, 2021). Weather data from "World Weather Online" was used to check ground level weather conditions (https: / / www.worldweatheronline.com, accessed on 6 October 2021). The base map was made by "Google Earth Pro".

Acknowledgments: This research was partially supported by the Center for International Forestry Research (CIFOR) with funding from the Japanese government. We would like to thank to "The NCEP/NCAR 40-Year Reanalysis Project".

Conflicts of Interest: The author declare no conflict of interest.

\section{References}

1. Previdi, M.; Smith, K.L.; Polvani, L.M. Arctic amplification of climate change: A review of underlying mechanisms. Environ. Res. Lett. 2021, 16, 093003. [CrossRef]

2. Delmotte, M.V.; Zhai, P.; Pirani, A.; Connorsv, S.L.; Péanv, C.; Berger, S.; Caud, N.; Chen, Y.; Goldfarbv, L.; Gomis, M.I.; et al. (Eds.) IPCC, 2021: Summary for Policymakers. In Climate Change 2021: The Physical Science Basis, Contribution of Working Group I to the Sixth Assessment Report of the Intergovernmental Panel on Climate Change; Cambridge University Press: Cambridge, UK, in press.

3. Flannigan, M.D.; Amiro, B.D.; Logan, K.A.; Stocks, B.J.; Wotton, B.M. Forest fires and climate change in the 21st century. In Mitigation and Adaptation Strategies for Global Change; Springer: Berlin/Heidelberg, Germany, 2006; Volume 11, pp. 847-859.

4. McCarty, J.L.; Aalto, J.; Paunu, V.-V.; Arnold, S.R.; Eckhardt, S.; Klimont, Z.; Fain, J.J.; Evangeliou, N.; Venäläinen, A.; Tchebakova, N.M.; et al. Reviews and syntheses: Arctic fire regimes and emissions in the 21st century. Biogeosciences 2021, 18, 5053-5083. [CrossRef]

5. Gillett, N.P.; Weaver, A.J.; Zwiers, F.W.; Flannigan, M.D. Detecting the effect of climate change on Canadian forest fires. Geophys. Res. Lett. 2004, 31, 18211. [CrossRef]

6. Duffy, P.A.; Walsh, J.E.; Graham, J.M.; Mann, D.H.; Rupp, T.S. Impacts of large scale atmospheric-Ocean variability on Alaskan fire season severity. Ecol. Appl. 2005, 15, 1317-1330. [CrossRef]

7. Flannigan, M.D.; Logan, K.A.; Amiro, B.D.; Skinner, W.R.; Stocks, B.J. Future area burned in Canada. Clim. Chang. 2005, 72, 1-16. [CrossRef]

8. IPCC. Climate change 2014: Impacts, adaptation, and vulnerability. Summaries, frequently asked questions, and cross-chapter boxes. In A Contribution of Working Group II to the Fifth Assessment Report of the Intergovernmental Panel on Climate Change; Field, C.B., Barros, V.R., Eds.; World Meteorological Organization: Geneva, Switzerland, 2014; p. 190.

9. Ponomarev, E.I.; Kharuk, V.I.; Ranson, K.J. Wildfires Dynamics in Siberian Larch Forests. Forests 2016, 7, 125. [CrossRef] 
10. Conard, S.G.; Sukhinin, A.I.; Stocks, B.J.; Cahoon, D.R.; Davidenko, E.P.; Ivanova, G.A. Determining effects of area burned and fire severity on carbon cycling and emissions in Siberia. Clim. Chang. 2002, 55, 197-211. [CrossRef]

11. Shvidenko, A.Z.; Schepaschenko, D.G. Climate Change and Wildfires in Russia. Contemp. Probl. Ecol. 2013, 6, 683-692. [CrossRef]

12. Federal State Statistics Service. Available online: http:/ /www.gks.ru (accessed on 29 February 2016).

13. Forkel, M.; Thonicke, K.; Beer, C.; Cramer, W.; Bartalev, S.; Schmullius, C. Extreme fire events are related to previous-year surface moisture conditions in permafrost-underlain larch forests of Siberia. Environ. Res. Lett. 2012, 7, 1-9. [CrossRef]

14. Kharuk, V.I.; Ranson, K.J.; Dvinskaya, M.L.; Im, S.T. Wildfires in northern Siberian larch dominated communities. Environ. Res. Lett. 2011, 6, 1-7. [CrossRef]

15. Krylov, A.; McCarty, J.L.; Potapov, P.; Loboda, T.; Tyukavina, A.; Turubanova, S.; Hansen, M.C. Remote sensing estimates of stand-replacement fires in Russia, 2002-2011. Environ. Res. Lett. 2014, 9, 1-8. [CrossRef]

16. Abatzoglou, J.T.; Crystal, A.K. Relative importance of weather and climate on wildfire growth in interior Alaska. Int. J. Wildland Fire 2011, 20, 479-486. [CrossRef]

17. Bell, G. Special Climate Summary, April-July 2004, Hot in Alaska, Cool over Central North America, Wet in South-Central U.S. Available online: http://www.cpc.ncep.noaa.gov/products/expert_assessment/alaska.pdf (accessed on 27 October 2015).

18. Wendler, G.; Conner, J.; Moore, B.; Shulski, M.; Stuefer, M. Climatology of Alaskan wildfires with special emphasis on the extreme year of 2004. Theor. Appl. Clim. 2010, 104, 459-472. [CrossRef]

19. Fauria, M.; Johnson, E.A. Large-scale climatic patterns control large lightning fire occurrence in Canada and Alaska forest regions. J. Geophys. Res. Biogeosci. 2006, 111, G04008. [CrossRef]

20. Fauria, M.; Johnson, E.A. Climate and wildfires in the North American boreal forest. Philos. Trans. R. Soc. B Biol. Sci. 2007, 363, 2315-2327. [CrossRef] [PubMed]

21. Skinner, W.R.; Stocks, B.J.; Martell, D.L.; Bonsal, B.; Shabbar, A. The association between circulation anomalies in the midtroposphere and area burned by wildland fire in Canada. Theor. Appl. Clim. 1999, 63, 89-105. [CrossRef]

22. Skinner, W.R.; Flannigan, M.D.; Stocks, B.J.; Martell, D.L.; Wotton, B.M.; Todd, J.B.; Mason, J.A.; Logan, K.A.; Bosch, E.M. A 500 hPa synoptic wildland climatology for large Canadian forest fires 1959-1996. Theor. Appl. Clim. 2002, 71, 157-169. [CrossRef]

23. Hayasaka, H.; Fukuda, M.; Kushida, K. Recent Large-scale Forest Fires in Boreal Forests and Climate Change-Discussion Based on Forest Fire and Weather Data in Alaska and Sakha. J. JAFSE 2007, 57, 45-51. (In Japanese)

24. Hayasaka, H. Recent Vegetation Fire Incidence in Russia. Glob. Environ. Res. 2011, 15, 5-13.

25. Hayasaka, H.; Tanaka, H.L.; Bieniek, P.A. Synoptic-scale fire weather conditions in Alaska. Polar Sci. 2016, 10, 217-226. [CrossRef]

26. Hayasaka, H.; Yamazaki, K.; Naito, D. Weather conditions and warm air masses in southern Sakha during active wildfire periods. J. Disaster Res. 2019, 14, 641-648. [CrossRef]

27. Hayasaka, H.; Yamazaki, K.; Naito, D. Weather Conditions and Warm Air Masses during Active Fire-periods in Boreal Forests. Polar Sci. 2019, 22, 100472. [CrossRef]

28. Hayasaka, H.; Sokolova, G.V.; Ostroukhov, A.; Naito, D. Classification of Active Fires and Weather Conditions in the Lower Amur River Basin. Remote Sens. 2020, 12, 3204. [CrossRef]

29. Shahgedanova, M. Climate at present and in the historical past. In The Physical Geography of Northern Eurasia; Oxford University Press: Oxford, UK, 2003; pp. 70-102. Available online: http://www.rusnature.info/geo/03_2.htm (accessed on 25 November 2021).

30. Kalnay, E.; Kanamitsu, M.; Kistler, R.; Collins, W.; Deaven, D.; Gandin, L.; Iredell, M.; Saha, S.; White, G.; Woollen, J.; et al. The NCEP/NCAR 40-year reanalysis project. Bull. Am. Meteorol. Soc. 1996, 77, 437-470. [CrossRef]

31. Carbon Brief, Jet Stream: Is Climate Change Causing More 'Blocking' Weather Events? Available online: https:/ / www.carbonbrief. org/jet-stream-is-climate-change-causing-more-blocking-weather-events (accessed on 8 October 2021).

32. Reigate Grammar School Weather Station, HIGH Pressure: Windy Round the Edges, a Bit on Super-Geostrophic Winds. Available online: https://rgsweather.com/2015/02/09/high-pressure-windy-round-the-edges-a-bit-on-super-geostrophicwinds/ (accessed on 8 October 2021). 